\section{Maturity onset diabetes of young type 2 due to a novel de novo GKC mutation}

\author{
Diabetes monogênica tipo MODY com início na juventude causado \\ por uma mutação GKC de novo não descrita anteriormente
}

Paula Afonso', Nélia Ferraria', Alexandre Carvalho', Sofia Vidal Castro'

\section{SUMMARY}

${ }^{1}$ Hospital Nossa Senhora do Rosário, Centro Hospitalar Barreiro Montijo, Portugal

\footnotetext{
Correspondence to:

Paula Afonso

Hospital Nossa Senhora do Rosário Centro Hospitalar Barreiro Montijo Departamento de Pediatria Av. Movimento das Forças Armadas 2830-094 - Barreiro, Portugal paulaafonso@hotmail.com

Received on Nov/27/2013 Accepted on Aug/18/2014
} DOI: $10.1590 / 0004-2730000003147$
Maturity Onset Diabetes of Young (MODY) is a heterogeneous group of monogenic disorders that result in $\beta$-cell dysfunction, with an estimated prevalence of $1 \%-2 \%$ in industrialized countries. MODY generally occurs in non-obese patients with negative autoantibodies presenting with mild to moderate hyperglycemia. The clinical features of the patients are heterogeneous, depending on the different genetic subtypes. We pretend to report a case of MODY type 2 caused by a novel de novo CGK mutation, highlighting the importance of the differential diagnosis in pediatric diabetes. A 13-year-old, healthy and non-obese girl was admitted for investigation of recurrent hyperglycemia episodes. She presented with persistent high levels of fasting blood glycemia (> $11.1 \mathrm{mmol} / \mathrm{L}$ ) and had no familial history of diabetes. The blood glucose profile revealed an impaired fasting glucose of $124 \mathrm{mg} / \mathrm{dL}(6,9 \mathrm{mmol} / \mathrm{L})$ with a normal oral glucose tolerance test. Fasting insulinemia was $15 \mathrm{mg} / \mathrm{dL}$ (90.1 pmol/L), HOMA-IR was 3.9 and hemoglobin A1c was $7.1 \%$. Pancreatic autoantibodies were negative. Genetic testing identified a novel missense heterozygous mutation in exon 5 of GCK gene c.509G > T (p.Gly170Val), not present on the parents. This result established the diagnosis of MODY type 2. Clinical identification of patients with MODY remains a diagnostic challenge, especially when familial history is absent. Molecular diagnosis is very important for establishing an individualized treatment and providing a long term prognosis for each type of MODY. Arq Bras Endocrinol Metab. 2014;58(7):772-5

\section{SUMÁRIO}

O diabetes da maturidade com início na juventude (MODY) é um grupo heterogêneo de doenças monogênicas que resultam em disfunção das células $\beta$, com uma prevalência estimada de 1-2\% nos países industrializados. O MODY geralmente ocorre em pacientes não obesos, negativos para autoanticorpos e que apresentam hiperglicemia de leve a moderada. As características clínicas dos pacientes são heterogêneas e dependem do subtipo genético. Pretende-se relatar um caso de MODY tipo 2 causado por uma mutação GKC de novo não descrita anteriormente, demonstrando a importância do diagnóstico diferencial no diabetes pediátrico. Uma menina de 13 anos de idade, saudável e não obesa, foi admitida em um hospital para investigação de episódios recorrentes de hiperglicemia. Ela apresentava níveis altos e persistentes de glicemia de jejum (> 11,1 mmol/L) e não havia histórico familiar de diabetes. 0 perfil glicêmico sanguíneo revelou glicose de jejum de $124 \mathrm{mg} / \mathrm{dL}$ (6,9 mmol/L), com resultados normais no teste oral de tolerância à glicose. $O$ resultado da insulinemia de jejum foi $15 \mathrm{mg} / \mathrm{dL}$ (90,1 pmol/L), do HOMA-IR foi 3,9 e da hemoglobina A1c foi de 7,1\%. Os autoanticorpos pancreáticos foram negativos. $A$ análise genética identificou uma nova mutação heterozigota missense no éxon 5 do gene GCK c.509G > T (p.Gly170Val), não encontrada nos país. Esse resultado estabeleceu o diagnóstico de MODY tipo 2. A identificação clínica dos pacientes com MODY permanece um desafio diagnóstico, especialmente quando não existe um histórico familiar. 0 diagnóstico molecular é muito importante para se estabelecer um tratamento individualizado e oferecer um prognóstico de longo prazo para cada tipo de MODY. Arq Bras Endocrinol Metab. 2014;58(7):772-5 


\section{INTRODUCTION}

$\mathrm{M}$ aturity onset diabetes of the young (MODY) is a heterogeneous group of monogenic disorders that result in $\beta$-cell dysfunction. It has an estimated prevalence of just $1 \%-2 \%$ of all diabetes in industrialized countries, however this prevalence is probably underestimated since large population screening studies have not been performed (1).

The first clinical case reports were described in the 1970s, as a familial form of noninsulin-dependent diabetes with autosomal dominant inheritance, presenting before the age of 25 years $(2,3)$. The molecular genetic basis of MODY was subsequently recognized in the 1990s (4-8) and diagnostic genetic testing for common subtypes followed rapidly. To date, 13 different genetic etiologies associated with different clinical features have been identified (9-11). The clinical features of patients with MODY are heterogeneous, depending on the different genetic subtypes.

There may be an overlap between MODY's clinical presentation and type 1 and type 2 diabetes, but an accurate diagnosis must be achieved in order to establish the proper management and treatment.

The typical clinical picture in MODY, as well as the prognosis and specific treatment response, are extremely dependent on the genetic etiology. Mutations in the genes encoding the enzyme glucokinase (GCK) and the nuclear transcription factors hepatocyte nuclear factor $1 \alpha(H N F I A)$ and hepatocyte nuclear factor $4 \alpha$ $(H N F 4 A)$ are the most common causes of MODY. GCK mutations are more commonly diagnosed in countries where glucose screening in asymptomatic people is a routine procedure (such as Germany, France, Spain and Italy), whereas HNFIA-MODY is more commonly diagnosed were routine glucose screening is seldom done $(12,13)$. There also some reported MODY cases in Brazilian literature (14-18).

\section{CASE REPORT}

We report the case of a 13-year-old girl admitted to Diabetes Consultation for investigation of recurrent hyperglycemia episodes.

Her family background was unremarkable, with no familial history of diabetes.

She was the second child of non-consanguineous parents. She had an uneventful full term gestation with a cesarean delivery. Her birth weight was on the $10^{\text {th }}$ percentile. She had no complications in the neonatal period. She achieved all the developmental milestones. Her past medical history was unremarkable with no known allergies, hospitalizations or serious illnesses.

One year before being admitted in our Consultation, she performed routine blood screening that showed hyperglycemia with a fasting blood glycemia of $124 \mathrm{mg} / \mathrm{dL}(7,1 \mathrm{mmol} / \mathrm{L})$.

During that year, she presented with three episodes of postprandial blurred vision and dizziness. In routine evaluation she had persistently high levels of fasting blood glycemia, all superior to $200 \mathrm{mg} / \mathrm{dL}(11,1$ $\mathrm{mmol} / \mathrm{L})$. She had no history of polyphagia, polyuria, polydipsia or weight loss.

The physical examination was unremarkable with normal vital parameters and a body mass index of 18,2 $\mathrm{kg} / \mathrm{m}^{2}$.

A blood glucose profile was obtained, and she was found to have an impaired fasting glucose of $124 \mathrm{mg} / \mathrm{dL}$ $(6,9 \mathrm{mmol} / \mathrm{L})$ and a normal oral glucose tolerance test with a glucose increment of only $3 \mathrm{mg} / \mathrm{dL}(0,2$ $\mathrm{mmol} / \mathrm{L}$ ) after 120 minutes of glucose ingestion. Fasting insulinemia was $15 \mathrm{mg} / \mathrm{dL}(90,1 \mathrm{pmol} / \mathrm{L})$, HOMA-IR was 3.9 and hemoglobin Alc was slightly elevated with a level of 7,1\%. Pancreatic auto antibodies were negative.

Even though she had a negative familial history of diabetes, acute onset of Maturity Onset Diabetes of Young (MODY) was suspected and genetic testing was performed. Genomic DNA of the patient was isolated and PCR amplification of the pancreas-specific exon la as well as of exons 2-10 of the GCK gene was performed. Sequencing of the PCR products identified a novel missense heterozygous mutation encoded by exon 5 at position c.509G $>$ T resulting in the aminoacid change p.Glyl70Val.

Genetic study was also performed to the patient's parents, who were asymptomatic and showed no mutation on $G C K$ gene.

This novel mutation on GCK gene, associated with a typical MODY type 2 clinical picture, in the absence of the mutation on both parents, suggests we are in presence of a MODY type 2 caused by a novel de novo mutation.

Based on the diagnosis of MODY type 2, the proposed treatment was only a lifestyle modification with regular physical activity and a well balanced diet. The patient has been clinically stable and the last laboratory evaluation showed a fasting glycemia of $112 \mathrm{mg} / \mathrm{dL}$ $(6,2 \mathrm{mmol} / \mathrm{L})$ with a hemoglobin Alc of $5,7 \%$. 


\section{DISCUSSION}

MODY diagnosis in pediatric patients may be challenging, especially when establishing the differential diagnosis between monogenic, type 1 and type 2 diabetes.

Being the most frequent type of diabetes in pediatric age, type 1 diabetes can be easily misdiagnosed in children presenting with hyperglycemia due to monogenic diabetes. The fact that monogenic diabetes usually presents with normal insulin and $\mathrm{C}$ peptide values, negative pancreatic autoantibodies and rarely presents with ketoacidosis are important features that help distinguish between MODY and type 1 diabetes.

The main differences between monogenic and type 2 diabetes are the fact that monogenic diabetes usually doesn't present with insulin resistance features such as acanthosis nigricans, central obesity, hypertension and dyslipidemia. Generally both monogenic and type 2 diabetes have a marked familial history of diabetes.

In this particular case, as MODY is caused by a de novo mutation, the usual familial history is not present leading to diagnostic challenges. It was not possible to test affected relatives, as they were all asymptomatic, in order to investigate co-segregation with de novo diabetes/hyperglycaemia.

With this case report we emphasize the need of a high level of clinical suspicion in patients with a clinical typical picture of MODY but without the usual marked familial history.

GCK catalyzes the ATP-dependent phosphorylation of glucose in the first, rate-limiting step of glycolysis in pancreatic $\beta$-cell, which enables $\beta$-cell and the hepatocyte to respond appropriately to the degree of glycemia $(19,20)$.

To date more than 620 GCK gene mutations have been reported in over 1400 patients with GCK-MODY (21-23). The mutations are localized over the ten exons of the gene which encode the pancreatic beta cell isoform of glucokinase.

Heterozygous inactivating mutations include missense, nonsense, splicing and small deletions/insertions / duplications variants. Here we report a novel heterozygous missense mutation c.509G > T (p.Gly 170Val) on exon 5 of GCK gene. To our knowledge this mutation has not been reported before in the literature.

GCK mutations reset the glucose threshold and the insulin secretion becomes up regulated, producing a higher fasting glucose level (24).
Therefore patients demonstrate mild, stable fasting hyperglycemia (99-144 mg/dL; 5.5-8.0 mmol/L) that shows little deterioration with age. They generally are asymptomatic and diagnosis is usually established during routine screening, like in our patient. As there is no impairment in the insulin production, glucose levels rapidly return to normal after an oral glucose load, as described in this patient. Most patients with mutations in the GCK have a small increase in plasma glucose $(5,4$ $\mathrm{mg} / \mathrm{dL} / 0,3 \mathrm{mmol} / \mathrm{L}$ in $70 \%$ of patients) 2 hours after an oral glucose load (25).

In MODY type 2, glycated hemoglobin (HbAlc level) is usually below $8 \%$ and there seems to be neither diabetes related microvascular nor macrovascular complications associated (26-28).

Accounting for the lack of long-term complications and the fact that treatment in MODY type 2 seems to have little effect on glycemia and HbAlc $(29,30)$, the general consensus is that the majority of pediatric patients do not require medical treatment (31).

Molecular diagnosis is, therefore, very important for establishing an individualized treatment for each type of MODY and for providing a reliable long term prognosis for individual patients and their relatives.

Disclosure: no potential conflict of interest relevant to this article was reported.

\section{REFERENCES}

1. Ledermann HM. Is maturity onset diabetes at young age (MODY) more common in Europe than previously assumed? Lancet. 1995;345(8950):648.

2. Tattersall RB. Mild familial diabetes with dominant inheritance. $Q$ J Med. 1974;43(170):339-57.

3. Tattersall RB, Fajans SS. A difference between the inheritance of classical juvenile-onset and maturity-onset type diabetes of young people. Diabetes. 1975;24(1):44-53.

4. Yamagata K, Furuta H, Oda N, Kaisaki PJ, Menzel S, Cox NJ, et al. Mutations in the hepatocyte nuclear factor-4alpha gene in maturity-onset diabetes of the young (MODY1). Nature. 1996;384(6608):458-60.

5. Yamagata K, Oda N, Kaisaki PJ, Menzel S, Furuta H, Vaxillaire $\mathrm{M}$, et al. Mutations in the hepatocyte nuclear factor-1alpha gene in maturity-onset diabetes of the young (MODY3). Nature. 1996;384(6608):455-8.

6. Vionnet N, Stoffel M, Takeda J, Yasuda K, Bell Gl, Zouali H, et al. Nonsense mutation in the glucokinase gene causes early-onset non-insulin-dependent diabetes mellitus. Nature. 1992;356(6371):721-2.

7. HorikawaY, Iwasaki N, Hara M, Furuta H, Hinokio Y, Cockburn BN, et al. Mutation in hepatocyte nuclear factor-1 beta gene (TCF2) associated with MODY. Nat Genet. 1997;17(4):384-5.

8. Stoffers DA, Ferrer J, ClarkeWL, Habener JF. Early-onset type-II diabetes mellitus (MODY4) linked to IPF1. Nat Genet. 1997;17(2):138-9. 
9. Shepherd M, Ellis I, Ahmad AM, Todd PJ, Bowen-Jones D, Mannion $\mathrm{G}$, et al. Predictive genetic testing in maturity-onset diabetes of the young (MODY). Diabet Med. 2001;18(5):417-21.

10. Thanabalasingham G, Owen KR. Diagnosis and management of maturity onset diabetes of the young (MODY). BMJ. 2011;343:d6044.

11. Bonnefond A, Philippe J, Durand E, Dechaume A, Huyvaert M, Montagne $\mathrm{L}$, et al. Whole-exome sequencing and high throughput genotyping identified KCNJ11 as the thirteenth MODY gene. PLoS One. 2012;7(6):e37423.

12. Estalella I, Rica I, Perez de Nanclares G, Bilbao JR, Vazquez JA, San Pedro Jl, et al. Mutations in GCK and HNF-1 alpha explain the majority of cases with clinical diagnosis of MODY in Spain. Clin Endocrinol (Oxf). 2007;67(4):538-46.

13. Schober E, Rami B, Grabert M, Thon A, Kapellen T, Reinehr T, et al. Phenotypical aspects of maturity onset diabetes of the young (MODY diabetes) in comparison with type 2 diabetes mellitus (T2DM) in children and adolescents: experience from a large multicentre database. Diabet Med. 2009;26(5):466-73.

14. Giuffrida FM, Calliari LE, Manna TD, Ferreira JG, Saddi-Rosa P, Kunii IS, et al. A novel glucokinase deletion (p.Lys32del) and five previously described mutations co-segregate with the phenotype of mild familial hyperglycaemia (MODY2) in Brazilian families. Diabetes Res Clin Pract. 2013;100(2):e42-5.

15. Furusawa GK, Giuffrida FMA, Oliveira CSV, Chacra AR, Dib SA, Reis AF. Low prevalence of MODY2 and MODY3 mutations in Brazilian individuals with clinical MODY phenotype. Diabetes Res Clin Pract. 2008;81(3):e12-4.

16. Moises RS, Reis AF, Morel V, Chacra AR, Dib SA, Bellanne-Chantelot $C$, et al. Prevalence of maturity-onset diabetes of the young mutations in Brazilian families with autosomal-dominant early-onset type 2 diabetes. Diabetes Care. 2001;24(4):786-8.

17. Caetano LA, Jorge AAL, Malaquias AC, Trarbach EB, Queiroz MS, Nery $M$, et al. Incidental mild hyperglycemia in children: two MODY 2 families identified in Brazilian subjects. Arq Bras Endocrinol Metab. 2012;56:519-24.

18. Nogoroto V, Svidnicki PV, Bonatto N, Milléo FQ, Almeida MCA, Vicari MR, et al. New HNF-1 $\alpha$ nonsense mutation causes maturity-onset diabetes of the young type 3. Clinics. 2011;66:167-8.

19. Ellard S, Bellanne-Chantelot C, Hattersley AT; European Molecular Genetics Quality Network (EMON) MODY group. Best practice guidelines for the molecular genetic diagnosis of maturity-onset diabetes of the young. Diabetologia. 2008;51(4):546-53.

20. Matschinsky FM. Evolution of the glucokinase glucose sensor paradigm for pancreatic beta cells. Diabetologia. 1993;36(11):1215-7.
21. Osbak KK, Colclough K, Saint-Martin C, Beer NL, Bellanné-Chantelot C, Ellard S, et al. Update on mutations in glucokinase (GCK), which cause maturity-onset diabetes of the young, permanent neonatal diabetes, and hyperinsulinemic hypoglycemia. Hum Mutat. 2009;30(11):1512-26.

22. Davis EA, Cuesta-Muñoz A, Raoul M, Buettger C, Sweet I, Moates $\mathrm{M}$, et al. Mutants of glucokinase cause hypoglycaemia- and hyperglycaemia syndromes and their analysis illuminates fundamental quantitative concepts of glucose homeostasis. Diabetologia. 1999;42(10):1175-86.

23. Gloyn AL. Glucokinase (GCK) mutations in hyper and hypoglycemia: maturity-onset diabetes of the young, permanent neonatal diabetes, and hyperinsulinemia of infancy. Hum Mutat. 2003;22(5):353-62.

24. Byrne MM, Sturis J, Clément K, Vionnet N, Pueyo ME, Stoffel M, et al. Insulin secretory abnormalities in subjects with hyperglycemia due to glucokinase mutations. J Clin Invest. 1994;93(3):112030 .

25. Stride A, Vaxillaire M, Tuomi T, Barbetti F, Njølstad PR, Hansen $\mathrm{T}$, et al. The genetic abnormality in the beta cell determines the response to an oral glucose load. Diabetologia. 2002;45(3):42735.

26. Martin D, Bellanne-Chantelot C, Deschamps I, Froguel P, Robert JJ, Velho G. Long-term follow-up of oral glucose tolerance test-derived glucose tolerance and insulin secretion and insulin sensitivity indexes in subjects with glucokinase mutations (MODY2). Diabetes Care. 2008;31(7):1321-3.

27. Velho $G$, Blanché $H$, Vaxillaire $M$, Bellanné-Chantelot $C$, Pardini VC, Timsit J, et al. Identification of 14 new glucokinase mutations and description of the clinical profile of 42 MODY-2 families. Diabetologia. 1997;40(2):217-24.

28. Steele AM, Shields BM, Shepherd M, Ellard S, Colclough K, Hattersley AT. Microvascular complication risk in patients with 50 years of moderate hyperglycaemia: are target ranges for glycaemic control appropriate? Abstract A77. Diabet Med. 2011;28(S1):2.

29. Hattersley AT, Pearson ER. Minireview: pharmacogenetics and beyond the interaction of therapeutic response, beta-cell physiology, and genetics in diabetes. Endocrinology. 2006;147(6):2657-63.

30. Gill-Carey OJ, Shields B, Colclough K, Ellard S, Hattersley AT. Finding a glucokinase mutation alters treatment [abstract]. Diabet Med. 2007;24(Suppl 1):A6-A20.

31. Hattersley A, Bruining J, Shield J, Njolstad P, Donaghue KC. The diagnosis and management of monogenic diabetes in children and adolescents. Pediatr Diabetes. 2009;10 Suppl 12:33-42. 